\title{
Effect of Growth Hormone Suppression on Exercise Training and Growth Responses in Young Rats
}

\author{
DAN M. COOPER, DAVID MOROMISATO, STEFANIA ZANCONATO, MARK MOROMISATO, \\ STEVEN JENSEN, AND JO ANNE BRASEL
}

Divisions of Respiratory and Critical Care and Endocrinology: Department of Pediatrics, Harbor-UCLA Medical

Center, Torrance, California 90509.2910

\begin{abstract}
Exercise training improves maximal oxygen uptake and endurance times in adult human beings and other animals. The mechanism of this improvement results in part from anabolic effects of exercise and may be mediated by growth hormone (GH). Little is known about the role of $\mathbf{G H}$ in the adaptation to exercise in younger, stilldeveloping organisms. To examine this role, we began a 4wk treadmill exercise training protocol in 14-d-old female rats. GH was suppressed by passive immunization with anti-GH releasing hormone antisera. There were four experimental groups: 1) GH-control (normal GH secretory capacity), untrained $(n=21) ; 2) \mathrm{GH}$-suppressed, untrained $(n=13)$; 3) GH-control, trained $(n=14)$; and 4) GHsuppressed; trained $(n=11)$. At the end of the training period, maximal oxygen uptake and treadmill endurance running time were measured. Serum GH and IGF-I were assessed using RIA, and whole hind limb musculature succinate dehydrogenase (an indicator of mitochondrial function) was measured with standard fluorometric technique. Body weight gain was markedly reduced in GHsuppressed rats (mean, $54 \%$ of $\mathrm{GH}$-controls in untrained rats and $55 \%$ in trained; $p<0.05$ ). No apparent effect of training on linear growth was observed. As expected, serum IGF-I was markedly reduced by GH suppression, but no exercise-induced increase occurred in IGF-I as a result of training in either the GH-control or GH-suppressed rats. In GH-control rats, maximal oxygen uptake and succinate dehydrogenase were $69 \%$ and $25 \%$ greater, respectively, in trained compared with untrained rats $(p<0.05)$. Despite GH inhibition, similar increases were found in the trained GH-suppressed rats (68\% greater than controls for maximal oxygen uptake and $34 \%$ for succinate dehydrogenase, $p<0.05$ ). Thus, marked improvement in cardiorespiratory function occurs with training in young female rats even when normal pituitary GH function is suppressed. (Pediatr Res 35: 223-227, 1994)
\end{abstract}

\section{Abbreviations}

GH, growth hormone

GHRH, growth hormone releasing hormone

$\mathrm{SDH}$, succinate dehydrogenase

Received August 4. 1993; accepted September 27, 1993.

Correspondence: Dan M. Cooper, M.D., Harbor-UCLA Medical Center. Box 491. Torrance, CA 90509-2910.

Supported by USPHS Grants HD26939 and HL11907, by General Clinical Research Grant RR00425, and by the Children's Hospital of Orange County Research and Education Foundation. D.M.C. is a recipient of the Career Investigator Award of the American Lung Association.

\author{
$\dot{V}_{2}$, oxygen uptake \\ Vo,max, maximal oxygen uptake
}

In mature human beings and animals of many species, increased physical activity leads to improved functional capabilities often measured as increased $\dot{\mathrm{V}}_{2}$ max or exercise endurance time. A pivotal mechanism for the improved function is the unique, naturally occurring anabolic effects of exercise (1), such as skeletal and cardiac muscle hypertrophy (2), increased capillarization and mitochondria (3), and increased bone density (4). Because exercise stimulates $\mathrm{GH}$ secretion (5) and because GH (either directly or in combination with IGF-I) is a potent growth factor for skeletal and heart muscle (6-9), it is not surprising that many investigations in both human beings $(10,11)$ and other species (12-14) indicate that GH plays an important role in the adaptation to exercise. Despite this finding, the role of $\mathrm{GH}$ in exerciseinduced growth is not understood, and evidence exists that exogenous $\mathrm{GH}$ administration does not enhance the effect of exercise training on muscle growth or strength in young, welltrained adult males (15-17).

Far less is known about responses to repeated bouts of physical activity in the younger, developing organism where overall body growth is rapid and secretory patterns of growth factors (such as $\mathrm{GH}$ ) are in a state of flux (18). The purpose of this experiment was to determine the role of $\mathrm{GH}$ in functional adaptations to exercise during development and to determine the effects of $\mathrm{GH}$ suppression and exercise training on somatic growth and circulating IGF-I. Prepubertal rats were exposed to a 4-wk period of treadmill exercise training, and we measured growth effects and cardiorespiratory responses to exercise in control rats and in rats with suppressed GH secretory capacity.

The experimental design consisted of training (treadmill exercise) young rats in whom normal GH secretion was blocked. Hypophysectomy has been used previously in the mature rat to obliterate any possible effect of exercise on GH secretion (19, 20 ), but this invasive surgical technique is technically more difficult in younger rats, results in reduced spontaneous physical activity, and requires the administration of other pituitary hormones to maintain health. As an alternative approach to attenuate GH secretion, we administered anti-GHRH antiserum. This antiserum was previously shown by Wehrenberg et al. (21) to markedly inhibit somatic growth, GH, and IGF-I in rats. The treatment was not accompanied by any apparent side effects.

The hypotheses of this study were as follows: $l$ ) in young rats, exercise training will result in marked functional responses reflecting anabolic effects mediated by GH-dependent mechanisms; 2) in young rats, somatic growth will be enhanced by exercise training caused by increased GH secretion and circulat- 
ing IGF-I; and 3) blocking normal pituitary secretion of $\mathrm{GH}$ will markedly attenuate the anabolic effects of physical activity.

\section{MATERIALS AND METHODS}

Sample population and protocol. A total of 59 female SpragueDawley rats were used. Rats from mixed litters were brought to the laboratory at $10 \mathrm{~d}$ of age in litters of 10 accompanied by a dam and allowed to become familiar with their surroundings and handlers. The animals were weighed, and tail length was measured. Rats were fed standard rat food and allowed food and water ad libitum. Food intake was not recorded.

The study was designed to examine four groups of animals: $I)$ GH-control (normal GH secretory capacity), untrained $(n=21)$; 2) GH-suppressed (by passive immunization with anti-GHRH antibodies), untrained $(n=13) ; 3) \mathrm{GH}$-control, trained $(n-14)$; and 4) GH-suppressed, trained $(n=11)$.

GH-suppressed rats received s.c. injections of $250 \mu \mathrm{L}$ of rabbit anti-GHRH antisera three times weekly beginning on $\mathrm{d} 13$ of life. The anti-GHRH antisera was generously provided to us by Dr. William Wehrenberg. GH-control rats received s.c. injections of $250 \mu \mathrm{L}$ of control rabbit serum three times weekly. Training began at $\mathrm{d} 14$ of life, and rats were separated from the dam at $\mathrm{d}$ 21 of life. We used a 4-wk, treadmill training protocol developed by MacIntosh and Baldwin (22) that was specifically designed for neonatal rats and one demonstrated to result in increased muscle cytochrome oxidase activity. Throughout the 4 -wk training period, running duration, treadmill incline, and treadmill speed increased progressively so that by the end of training, rats in both training groups ran for $60 \mathrm{~min}$ at a $25 \%$ incline and at a speed of $28 \mathrm{~m} / \mathrm{min}$.

At the end of the training period, the rats were weighed, and tail length was measured. Each rat underwent a progressive treadmill exercise test to exhaustion to determine $\dot{V}_{\mathrm{O}_{2}} \max$ and maximal running time. Because untrained rats were unfamiliar with the treadmill, they were allowed 10 -min periods of lowspeed, $0 \%$ incline treadmill running for 3-4 d before the end of the 4-wk experimental period. On the day after the $\dot{\mathrm{V}}_{2}$ max test, the animals were killed. Blood was obtained from left ventricular puncture. The whole hind limb musculature was carefully dissected from bone and other tissues, immediately frozen at $-70^{\circ} \mathrm{C}$, and saved for subsequent analysis.

Measurement of $\mathrm{VO}_{2} \max$. Gas exchange was measured using an open-circuit, constant room air flow through system in which flow was measured using pneumotachographs, and $\mathrm{O}_{2}, \mathrm{CO}_{2}$, and $\mathrm{N}_{2}$ concentrations were measured with a mass spectrometer. Standard Haldane corrections were applied to the final calculations of $\dot{\mathrm{V}}_{2}$. The system was calibrated by administering gases of known $\mathrm{O}_{2}, \mathrm{CO}_{2}$, and $\mathrm{N}_{2}$ concentrations at precisely controlled flow rates. The error of $\dot{\mathrm{V}}_{2}$ measurement was $\pm 3 \%$.

$\mathrm{V}_{2} \max$ tests were performed at $0 \%$ incline. A 3-min rest/ acclimation period was followed by an initial treadmill speed of $18 \mathrm{~m} / \mathrm{min}$ for $3 \mathrm{~min}$. Thereafter, treadmill speed increased by 9 $\mathrm{m} / \mathrm{min}$ every $3 \mathrm{~min}$ until the rats were unable to continue running. We anticipated that the GH-suppressed and $\mathrm{GH}$-control groups would differ greatly in body weight; thus, to compare $\mathrm{VO}_{2} \mathrm{max}$ in different-sized animals, the value was normalized to body weight. Moreover, resting (i.e. preexercise) metabolic rate normalized to body weight is larger in smaller animals (23). Thus, to further minimize the confounding effects of body size alone, we subtracted the $\mathrm{VO}_{2}$ during the few minutes immediately before the exercise test from the maximum value and used this variable $\left[\mathrm{V}_{2}(\max -\right.$ pretest $)$ ], the actual increase in metabolic rate resulting from the exercise, to compare exercise responses among the different-sized rats.

Measurement of serum $G H$ and IGF-I. An RIA was used to measure serum $\mathrm{GH}$ using World Health Organization standard no. $66 / 217$, polyclonal antisera generated in-house and hGH from NIDDK for iodination purposes. The GH intraassay variability is less than $10 \%$, interassay variability is $12.6 \%$, and the sensitivity is $0.5 \mu \mathrm{g} / \mathrm{L}$. RIA are currently used in our laboratory for human IGF-I with antibodies provided by the National Institutes of Health and standards purchased from Bachem. The intraassay coefficient of variation is $3.3 \%$, and interassay coefficient is $5.4 \%$. We used the acid ethanol extraction method (24) to extract IGF-I from binding proteins.

Measurement of hind limb muscle SDH activity. Briefly, muscle tissue was homogenated in phosphate buffer, centrifuged, and the supernatant extracted. SDH activity was determined using a standard two-step reaction as described by Henriksson et al. (25). In this assay, fluorometric techniques gauge the rate of conversion of NADH to NAD in individual tissue samples, and this measurement is a reflection of SDH activity. The intraassay coefficient of variation is $5 \%$. Data are expressed per gram of wet weight of muscle.

Statistical analyses. Randomized analysis of variance was used to compare variables in the four groups. When analysis of variance was significant, intergroup comparisons were tested using Duncan's modification of $t$ test. Results are presented as mean \pm 1 SD. Statistical significance was achieved at the $p<$ 0.05 level.

These studies were approved by the animal care and use review committee of Harbor-UCLA Medical Center.

\section{RESULTS}

Somatic growth. Body weights were substantially reduced in the GH-suppressed rats (Fig. 1). Tail length results were qualitatively similar. In untrained rats, tail length in the $\mathrm{GH}$-control group $(155 \pm 4 \mathrm{~mm})$ was significantly greater than in $\mathrm{GH}$ suppressed rats $(130 \pm 5 \mathrm{~mm})$. Similarly, in the trained rats, tail length was significantly greater in the GH-control group (155 \pm $4 \mathrm{~mm}$ ) than in the GH-suppressed group (130 $\pm 5 \mathrm{~mm})$. No independent effect of exercise training on body weight or tail length in either the GH-suppressed or GH-control rats was observed.

$\dot{V} \mathrm{O}_{2}$ max and maximal running time. $\dot{\mathrm{V}}_{2}(\max$ - pretest) was significantly greater in trained versus untrained rats in both the $\mathrm{GH}$-control and GH-suppressed groups (Fig. 2). Although the mean value of the $\mathrm{VO}_{2}(\max$ - pretest $)$ was actually greater in the $\mathrm{GH}$-suppressed trained rats than in the GH-control trained rats, the values were not statistically different. Results of treadmill running times were qualitatively similar to the $\dot{V}_{\mathrm{O}_{2}}$ (max - pretest) values. In the $\mathrm{GH}$-control rats, running time in the untrained group ( $13 \pm 2 \mathrm{~min})$ was significantly less than in trained rats $(20$ $\pm 4 \mathrm{~min}$ ); in the GH-suppressed rats, running time in the untrained group ( $17 \pm 3 \mathrm{~min}$ ) was significantly less than in the trained animals $(24 \pm 3 \mathrm{~min})$.

$S D H$ activity. SDH activity was significantly increased in trained rats in both the GH-control $(2.89 \pm 0.41 \mu \mathrm{mol} / \mathrm{g} / \mathrm{min}$ in

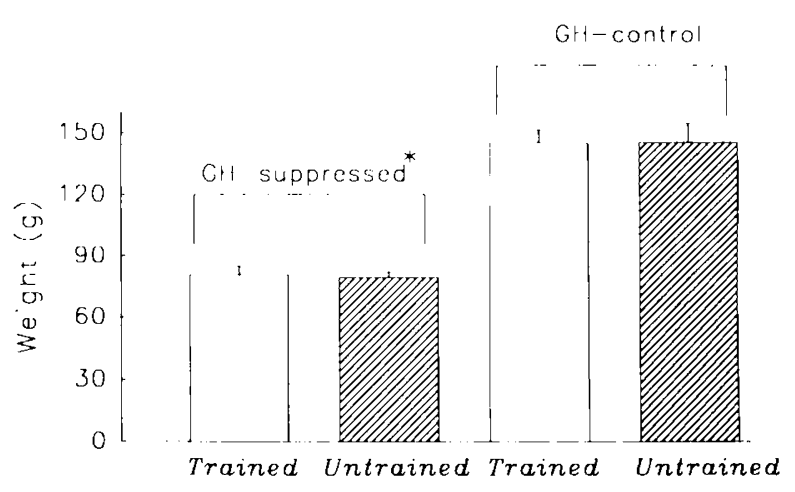

Fig. 1. Effect of anti-GHRH antisera on body weight in young female rats (mean $+\mathrm{SD}$ ). Four weeks of therapy resulted in marked reduction in body weight gain. No independent effect of exercise training on body weight was observed ${ }^{*} p<0.05$; both trained and untrained GHsuppressed rats weighed less than GH-control rats). 


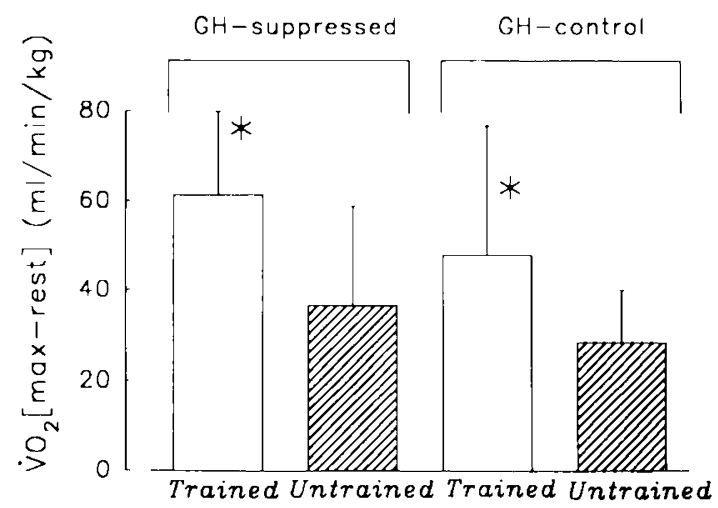

Fig. 2. Effect of treadmill training on $\dot{V}_{O_{2}} \max$ in $\mathrm{GH}$-suppressed and GH-control rats (mean $+\mathrm{SD}$ ). Training increased $\dot{V}_{()_{2} \text { max }}$ in both the $\mathrm{GH}$-suppressed and GH-control groups $\left({ }^{*} p<0.05\right)$.

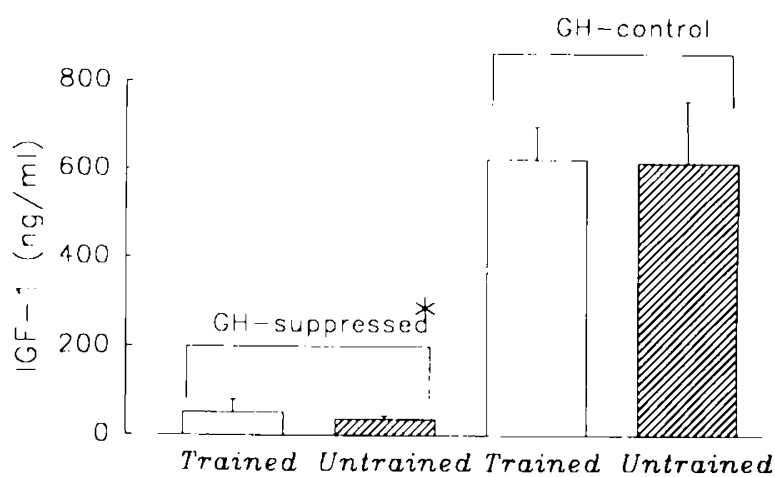

Fig. 3. Effect of anti-GHRH antisera on circulating IGF-I in trained and untrained rats (mean $+\mathrm{SD}$ ). As expected, IGF-I was markedly reduced in GH-suppressed rats. No independent effect of exercise training on IGF-I levels was observed $\left({ }^{*} p<0.05\right.$; both trained and untrained $\mathrm{GH}$-suppressed rats compared with $\mathrm{GH}$-control rats).

trained rats and $2.31 \pm 0.17 \mu \mathrm{mol} / \mathrm{g} / \mathrm{min}$ in untrained rats) and GH-suppressed groups $(3.06 \pm 0.28 \mu \mathrm{mol} / \mathrm{g} / \mathrm{min}$ in trained rats and $2.27 \pm 0.19 \mu \mathrm{mol} / \mathrm{g} / \mathrm{min}$ in untrained rats).

$G H$ and IGF-I. Circulating IGF-I (Fig. 3) was substantially reduced in the GH-suppressed rats. As expected. in untrained rats, mean $\mathrm{GH}$ in the $\mathrm{GH}$-control group $(41 \pm 37 \mu \mathrm{g} / \mathrm{L})$ was significantly greater than in GH-suppressed rats $(2 \pm 1 \mu \mathrm{g} / \mathrm{L})$. Similarly, in the trained rats. $\mathrm{GH}$ was significantly greater in the GH-control group ( $36 \pm 34 \mu \mathrm{g} / \mathrm{mL}$ ) than in the $\mathrm{GH}$-suppressed $(2 \pm 1 \mu \mathrm{g} / \mathrm{L})$. No effect of training on $\mathrm{GH}$ or IGF-I was observed in either the GH-control or GH-suppressed groups.

\section{DISCUSSION}

This study demonstrates that 4 wk of treadmill training in young female rats increased $\mathrm{V}_{2}$ max, maximal treadmill running time, and hind limb muscle SDH activity. These adaptations occurred even in the GH-suppressed rats (i.e those treated with anti-GHRH antibodies) in whom circulating GH and IGF-I levels were low. The $\mathrm{GH}$-suppressed rats were active, required no exogenous hormone replacement (as in the case in surgically hypophysectomized rats), and appeared to have no ill effects from the treatment per se. The marked growth retardation (Fig. 1) and substantially reduced serum levels of GH (Fig. 3) demonstrate the effectiveness of the anti-GHRH antisera. Our results are consistent with the studies of Goldberg (19) and Gollnick and Ianuzzo (20) who showed that muscle hypertrophy and increases in muscle SDH can occur either as a compensatory mechanism or in response to exercise in mature, hypophysectomized rats.

Several possible explanations exist for the apparent discrepancy between our results and previous observations supporting a role for $\mathrm{GH}$ in the training effect. First, growth factors such as IGF-I may be less dependent on GH in some tissues than previously thought. DeVol et al. (26), for example, demonstrated in rats that compensatory hind limb muscle hypertrophy was accompanied by increases in IGF-I mRNA of the hypertrophied muscle even in hypophysectomized rats. Thus, in addition to possible endocrine effects of circulating IGF-I originating in the liver and stimulated by GH, it appears that IGF-I can be produced in local tissues independently of $\mathrm{GH}$ and result in autocrine or paracrine growth stimulation (27).

Second, the training response likely represents the combined effects of a variety of stimuli and possibly multiple growth factors. In addition to IGF, evidence exists that fibroblast growth factor acts locally and, most likely, without direct $\mathrm{GH}$ control in exercise-induced anabolism (28). The fibroblast growth factors also play a particularly important role in vascular growth (29), observations that suggest a possible mechanism for the increased capillarization that accompanies physical training.

Gender, particularly in its interaction with puberty, may have played a role in how GH-suppressed rats responded to exercise training. Gender differences in fitness are virtually nonexistent in prepubertal children (30), and MacIntosh and Baldwin (22), whose training protocol was adapted for the present study, noted no gender differences in the effects of exercise on skeletal muscle oxidative capacity in neonatal rats. However, gender-related exercise effects become substantial in teenagers; one study demonstrated that American girls become progressively less fit than boys (30). In addition, the gender differences that do exist [e.g. differences in heart muscle responses in rats (31) and $\mathrm{Hb}$ in human beings (32)] are most often noted in mature, postpubertal subjects.

GH secretion increases in puberty $(18,33,34)$, along with marked increases in testosterone in males and estradiol in females. Testosterone appears to contribute to the high amplitude/ low baseline pattern of $\mathrm{GH}$ secretion observed in mature male rats, and estradiol leads to the low amplitude/high baseline pattern observed in mature females (25). Although not as dramatic as in rats, puberty in human beings is characterized by greater increase in spontaneous $\mathrm{GH}$ pulse frequency and amplitude in males compared with females $(34,36)$. It is possible that training effects in young females are therefore less $\mathrm{GH}$ dependent than in males. The interaction between hormonal changes associated with puberty and physical activity is not as yet well understood, but our data clearly demonstrate that female rats can respond robustly to exercise training initiated early in life.

Training did not increase circulating IGF-I in this sample of young female rats despite the training-induced increases in running time, $\mathrm{V}_{2} \mathrm{max}$, and muscle $\mathrm{SDH}$. The plasma concentration of IGF-I is determined by the net flux of IGF-I into the circulation and by the IGF-I volume of distribution; thus, an increase in concentration may not reflect an increase in production. The lack of change is in contrast to at least two cross-sectional studies in adult human beings $(4,37)$, which showed a positive correlation between serum IGF-I levels and physical fitness (assessed by the $\mathrm{V}_{2}$ max per kilogram of body weight). Presumably, exercise stimulated $\mathrm{GH}$, which over a period of time led to increased circulating IGF-I.

What might account for these apparent differences in the circulating IGF-I response to exercise training between previous studies in human beings and the present data? First, the GH and the related IGF-I response to exercise may differ among species. Although exercise increases circulating $\mathrm{GH}$ acutely in human beings, swimming, at least, is known to reduce serum $\mathrm{GH}$ in rats (38). Second, the effect of exercise on circulating IGF-I may depend on the maturational state of the subject. IGF-I levels increase in human beings and rats from birth, reaching their highest levels around puberty $(39,40)$. Similarly, GH secretory responses are greatest during puberty $(18)$ and fall with aging (41). In the present study, training was begun in the prepubertal phase and continued through early puberty. Perhaps the naturally 
occurring age-related increases in IGF-I that occur early in development cannot be further stimulated by exercise.

Consistent with this hypothesis are the observations of Deyssig et al. (17) and Yarasheski et al. $(15,16)$ who were unable to demonstrate an increase in body composition, muscle growth, or muscle protein synthesis after exogenous GH therapy. The subjects in these studies were highly trained, young adult male weight lifters who actively trained throughout the study period. Deyssig $e t$ al. found that serum IGF-I increased in the subjects receiving exogenous $\mathrm{GH}$ despite the lack of evidence that $\mathrm{GH}$ administration additionally increased muscle strength. Interestingly, the IGF-I in the control athletes was in the high normal range and did not change over the training period even though the subjects were actively training. Thus, factors such as levels of fitness, GH, and IGF-I status likely contribute to any potential effect of either $\mathrm{GH}$ administration or inhibition.

In our study, GH suppression markedly reduced linear growth, as previously described (21), but, in contrast to our hypothesis, the treadmill training program early in the lives of female rats did not increase body weight or tail length in either the GHcontrol or GH-suppressed rats. Little consensus exists regarding the short- or long-term effects of training programs during childhood in human studies (42). Some investigators have concluded that training increases growth velocity by a small but significant degree $(43,44)$; other workers could find no such activity-related growth effect despite a significant effect of training on $\dot{\mathrm{V}}_{2} \max$ and lung function $(45,46)$. Excessive training actually may have adverse effects on somatic growth in children and teenagers, particularly when nutrition is inadequate. For example, Theintz et al. (47) recently reported a reduction in the growth potential of adolescent female gymnasts engaging in vigorous training and dieting, and Jahreis et al. (48) demonstrated a reduction in serum IGF-I in female gymnasts (mean age, $11.7 \mathrm{y}$ ) after $3 \mathrm{~d}$ of intensive training. The precise role of $\mathrm{GH}$ in these observations has yet to be determined.

From a clinical perspective, the ways in which habitual physical activity during childhood can, through anabolic effects on muscles, heart, and blood vessels, beneficially influence health later in life (49) may prove to be more important than changes in body height or weight per se. The data presented here imply a potentially important role played by local tissue growth factors that can modulate anabolic effects of exercise even in the absence of $\mathrm{GH}$ in the young animal. The long-term adaptation to physical activity may be mediated by multiple or hierarchical factors such that the impairment or absence of one component does not completely inhibit anabolic responses to exercise.

Acknowledgments. The authors thank Maria Lajoie, B.S., for her technical assistance and Dr. William Wehrenberg for his generous gift of anti-GHRH antisera.

\section{REFERENCES}

1. Cooper DM 1994 Evidence for and mechanisms of exercise modulation of growth. Med Sci Sports Exerc (in press)

2. Pearson AM 1990 Muscle growth and exercise. Crit Rev Food Sci Nutr 29:167196

3. Blomqvist CG. Saltin B 1983 Cardiovascular adaptations to physical training. Annu Rev Physiol 45:169-189

4. Kelly PJ, Eisman JA. Stuart MC. Pocock NA. Sambrook PN, Gwinn TH 1990 Somatomedin-C, physical fitness, and bone density. J Clin Endocrinol Metab 70:718-723

5. Felsing NE. Brasel J, Cooper DM 1992 Effect of low- and high-intensity exercise on circulating growth hormone in men. J Clin Endocrinol Metab 75:157-162

6. Ayling CM. Moreland BH. Zanelli JM. Schulster D 1989 Human growth hormone treatment of hypophysectomized rats increases the proportion of type-1 fibres in skeletal muscle. J Endocrinol 123:429-435

7. Flaim KE, Li JB, Jefferson LS 1978 Protein turnover in rat skeletal muscle: effects of hypophysectomy and growth hormone. Am J Physiol 234:E38E43

8. Rodrigues EA. Caruana MP. Lahiri A. Nabarro JD. Jacobs HS. Raftery EB 1989 Subclinical cardiac dysfunction in acromegaly: evidence for a specific disease of heart muscle. Br Heart J 62:185-194
9. Siegel RJ, Fishbein MC, Said JW, Fealy M, Chai A. Rubin SA. Melmed S 1989 Identification of growth hormone at the myocardial cell surface. Am J Cardiovasc Pathol 2:345-350

10. Cuneo RC. Salomon F. Wiles CM. Hesp R. Sonksen PH 1991 Growth hormone treatment in growth hormone-deficient adults. II. Effects on exercise performance. J App! Physiol 70:695-700

11. Weltman A, Weltman JY, Schurrer R, Evans WS, Veldhuis JD, Rogol AD 1992 Endurance training amplifies the pulsatile release of growth hormone: effects of training intensity. J Appl Physiol 72:2188-2196

12. Borer KT. Kuhns LR 1977 Radiographic evidence for acceleration of skeletal growth in adult hamsters by exercise. Growth $41: 1-13$

13. Borer KT 1980 Characteristics of growth-inducing exercise. Physiol Behav 24:713-720

14. Grindeland RE, Roy R, Edgerton VR, Grossman E, Rudolph I, Pierotti D, Goldman B 1991 Exercise and growth hormone have synergistic effects on skeletal muscle and tibias of suspended rats. FASEB J 5:A 1037(Abstr)

15. Yarasheski KE. Campbell JA. Smith K. Rennie MJ. Holloszy JO. Bier DM 1992 Effect of growth hormone and resistance exercise on muscle growth in young men. Am J Physiol 262:E26!-E267

16. Yarasheski KE, Zachweija JJ, Angelopoulos TJ, Bier DM 1993 Short-term growth hormone treatment does not increase muscle protein synthesis in experienced weight lifters. J Appl Physiol 74:3073-3076

17. Deyssig R, Frisch H, Blum WF. Waldhor T 1993 Effect of growth hormone treatment on hormonal parameters, body composition and strength in athletes. Acta Endocrinol (Copenh) 128:313-318

18. Mauras N. Blizzard RM, Link K, Johnson ML, Rogol AD, Veldhuis JD 1987 Augmentation of growth hormone secretion during puberty: evidence for a pulse amplitude-modulated phenomenon. J Clin Endocrinol Metab 64:596601

19. Goldberg AL 1967 Work-induced growth of skeletal muscle in normal and hypophysectomized rats. Am J Physiol 213:1193-1198

20. Gollnick PD. Ianuzzo CD 1972 Hormonal deficiencies and the metabolic adaptations of rats to training. Am J Physiol 223:278-282

21. Wehrenberg WB, Bloch B. Phillips BJ 1984 Antibodies to growth hormonereleasing factor inhibit somatic growth. Endocrinology 115:1218-1220

22. MacIntosh AM, Baldwin KM 1983 Effects of repetitive exercise on neonatal rat skeletal muscle oxidative capacity. J Appl Physiol 54:530-535

23. Kleiber M 1975 The Fire of Life. Krieger, New York

24. Daughaday WH. Kapadia M. Mariz I 1987 Serum somatomedin binding proteins: physiologic significance and interference in radioligand assay. J Lab Clin Med 109:355-363

25. Henriksson J, Nygaard E. Andersson J. Eklof B 1980 Enzyme activities, fibre types and capillarization in calf muscles of patients with intermittent claudication. Scand J Clin Lab Invest 40:361-369

26. DeVol DL, Rotwein P. Sadow JL, Novakofski J, Bechtel PJ 1990 Activation of insulin-like growth factor gene expression during work-induced skeletal muscle growth. Am J Physiol 259:E89-E95

27. LeRoith D, Adamo M. Werner H. Roberts Jr CT 1991 Insulin-like growth factors and their receptors as growth regulators in normal physiology and pathologic states. Trends Endocrinol Metab 2:134-139

28. Morrow NG, Kraus WE, Moore JW. Williams S, Swain JL 1990 Increased expression of fibroblast growth factors in a rabbit skeletal muscle model of exercise conditioning. J Clin Invest 85:1816-1820

29. D'Amore PA 1992 Mechanisms of endothelial growth control. Am J Respir Cell Mol Biol 6:1-8

30. Cooper DM. Weiler Ravell D, Whipp BJ, Wasserman K 1984 Aerobic parameters of exercise as a function of body size during growth in children. $J$ Appl Physiol 56:628-6.34

31. Schaible TF, Penpargkul S, Scheuer J 1981 Cardiac responses to exercise training in male and female rats. J Appl Physiol 50:112-117

32. Telford RD, Cunningham RB 199/ Sex, sport, and body-size dependency of hematology in highly trained athletes. Med Sci Sports Exerc 23:788-794

33. Finkelstein JW, Roffwarg HP, Boyar RM, Kream J, Hellman L 1972 Agerelated change in the twenty-four hour spontaneous secretion of growth hormone. J Clin Endocrinol Metab 35:665-670

34. Costin G, Kaufman FR. Brasel J 1989 Growth hormone secretory dynamics in subjects with normal stature. J Pediatr 115:537-544

35. Hertz P. Silbermann M. Even L. Hochberg Z 1989 Effects of sex steroids on the response of cultured rat pituitary cells to growth hormone-releasing hormone and somatostatin. Endocrinology 125:581-585

36. Miller JD. Tannenbaum GS, Colle E, Guyda HJ 1982 Daytime pulsatile growth hormone secretion. J Clin Endocrinol Metab 55:989-994

37. Poehlman ET. Copeland KC 1990 Influence of physical activity on insulinlike growth factor-I in healthy younger and older men. J Clin Endocrinol Metab 71:1468-1473

38. Federspil G, Udeschini G, De Palo C. Sicolo N 1975 Role of growth hormone in lipid mobilization stimulated by prolonged muscular exercise in the rat. Horm Metab Res 7:484-488

39. LeRoith D. Adamo M. Roberts Jr CT (1990) Regulation of insulin-like growth factor-I gene expression. In: Sara VR. Hall K, Low H (eds) Growth Factors from Genes to Clinical Applications. Raven Press, New York, pp 11-24

40. LeRoith D, Roberts Jr CT 1991 Insulin-like growth factor I: a molecular basis for endocrine versus local action? Mol Cell Endocrinol 77:C57-61

41. Pyka G. Wiswell RA. Marcus R 1992 Age-dependent effect of resistance exercise on growth hormone secretion in people. J Clin Endocrinol Metab 75:404-407 
42. Rowland TW 1992 Trainability of the cardiorespiratory system during childhood. Can J Sport Sci 17:258-263

43. Astrand P-O. Engstrom L, Eriksson B, Karlberg P, Nylander I, Saltin B. Thoren C $1963 \mathrm{Girl}$ swimmers (with special reference to respiratory and circulatory adaptation). Acta Paediatr Scand 147:S1-S75

44. Milicer H. Denisuk L (1964) The physical development of youth. In: Jokl E. Simon E (eds) International Research in Sport and Physical Education. Charles C Thomas, Springtield, IL, pp 262-285

45. Sprynarova $S 1987$ The influence of training on physical and functional growth before, during, and after puberty. Eur J Appl Physiol 56:719-724
46. Mirwald RL. Bailey DA. Cameron N. Rasmussen RL 1981 Longitudinal comparison of aerobic power on active and inactive boys aged 7.0 to 17.0 years. Ann Hum Biol 8:405-414

47. Theintz GE. Howald H. Weiss U. Sizonenko PC 1993 Evidence for a reduction of growth potential in adolescent female gymnasts. J Pediatr 122:306-313

48. Jahreis G, Kauf E. Frohner G. Schmidt HE 1991 Influence of intensive exercise on insulin-like growth factor I, thyroid and steroid hormones in female gymnasts. Growth Regul 1:95-99

49. Strong WB 1990 Physical activity and children. Circulation 81:1697-1701 